\title{
Voiko peltobioenergiatuotanto vähentää happamilta sulfaattimailta tulevaa vesistökuormitusta?
}

\author{
Seija Virtanen ${ }^{1)}$, Asko Simojoki ${ }^{1)}$,Markku Yli-Halla ${ }^{1)} \&$ Matti Ylösmäki ${ }^{2)}$ \\ ${ }^{1)}$ Soveltavan kemian ja mikrobiologian laitos, 00014 Helsingin yliopisto, seija.virtanen@ helsinki.fi, \\ asko.simojoki@helsinki.fi,.markku.yli-halla@helsinki.fi, \\ ${ }^{2)}$ Maa-ja elintarviketalouden tutkimuskeskus,31600 Jokioinen, matti.ylosmaki@mtt.fi
}

Peltoviljelyssä olevista happamista sulfaattimaista purkautuu vesistöihin ajoittain hyvin hapanta ja runsaasti metalleja sisältävää kuivatusvettä. Vähäistä kuivatussyvyyttä vaativan ruokohelven viljely bioenergiatuotantoon saatttaisi olla yksi ratkaisu tähän ongelmaan näillä alueilla.

Tutkimus kuivatussyvyyden vaikutuksesta ruokohelven tuotantoon happamilla sulfaattimailla sekä kuivatussyvyyden ja kasvin vaikutuksesta valumaveden laatuun aloitettiin kesällä 2007 osana maatalous-metsätieteellisen tiedekunnan yhteistutkimushanketta "Peltobioenergiaketjut - raaka-aineen tuotanto ympäristöllisesti ja taloudellisesti kestävällä tavalla" esikokeilla, joissa selvitettiin, voidaanko happamilta sulfaattimailta otettuja suuria maanäytelieriöitä käyttää pelto-olojen simulointiin. Esikokeissa pyrittiin luomaan toimiva mittausjärjestelmä ennen laajemman kokeen aloittamista ja kasvullisten jäsenten mukaanottamista. Käytännön toteutukseen kehitettiin häiriintymättömien suurten maapatsaiden ottamisen tekniikka, vedensäätöjärjestelmä ja jatkuvatoimisten mittausten instrumentointi kahden suuren maanäytelieriön avulla.

Isot maalieriöt otettiin Viikin koetilan pellolta, joka on hapanta sulfaattimaata. Samalle peltolohkolle asennettiin pohjavesiputkia pohjaveden laadun ja korkeuden seuraamiseksi. Pohjaveden korkeuden vaihtelun aiheuttamia muutoksia maanäytelieriöissä verrattiin kasvukauden aikana pellolta mitattuihin pohjaveden laadun muutoksiin.

Maanäytelieriöistä mitattiin maan redox-potentiaalia sekä vesipitoisuutta, lämpötilaa ja sähkönjohtavuutta jatkuvatoimisesti 10 minuutin välein muokkauskerroksesta, hapettuneesta kerroksesta ja pelkistyneestä kerroksesta. Aineiston keräämiseen käytettiin dataloggereita (Agilent 34980A) ja (Degacon Em50), josta tulokset siirrettiin tietokoneelle. Maan pH-arvoa ja huokosveden koostumusta seurattiin määräajoin.

Redox-mittausten toteutus käyttämen suolasillan avulla toteuttua yhteistä referenssielektrodia kaikille Pt-elektrodeille antoi luotettavia tuloksia. Jatkuvatoimisen ja manuaalisen redox-mittauksen keskimääräinen ero oli pienin pelkistyneessä kerroksessa $(38 \mathrm{mV})$ ja hapettuneissa kerroksissa hieman isompi $(100 \mathrm{mV})$. Pohjaveden $\mathrm{pH}: \mathrm{n}$, sähkönjohtavuuden ja redox-potentiaalin muutokset pohjaveden korkeuden funktiona pellolla ja maanäytelieriöissä olivat samansuuntaisia. Pohjaveden pinnan nousu laski redox-potentiaalia ja sähkönjohtavuutta ja nosti veden/maan $\mathrm{pH}$-arvoa molemmissa.

Esikokeesta saadut alustavat tulokset viittaavat siihen, että maanäytelieriöllä voidaan simuloida pellolla tapahtuvia pohjaveden muutoksia ja seurata pohjaveden korkeuden vaikutusta maan ominaisuuksiin. Pohjaveden nostolla oli esitutkimuksessa $\mathrm{pH}$-arvoa nostava vaikutus, kuten aiemmissa happamilla sulfaattimailla tehdyissä tutkimuksissa on havaittu. Ruokohelven kasvu pohjaveden pinnan ollessa korkealla ja kasvin vaikutus maan ominaisuuksiin ja valumaveden laatuun on tutkimuksen seuraava vaihe. 


\section{Johdanto}

Viljanviljelyn vaatima kuivatus ja ympäristönäkökohdat ovat happamilla sulfaattimailla keskenään ristiriidassa. Pohjanmaan happamilla sulfaattimailla viljantuotannon vaatima kuivatussyvyys saattaa pelkistyneitä maakerroksia alttiiksi hapettumiselle. Syksyllä pohjaveden nousu ja runsaat sateet huuhtovat hapettuneista kerroksista vesistöihin hyvin hapanta kuivatusvettä, jossa on myös kohonneita metallipitoisuuksia (Roos ja Åström 2005). Seurauksena on mm. kalakuolemia laskuvesistöissä (Åström ja Björklund 1995).

Pohjaveden korkeuden nostaminen pienentää vesistökuormitusta, mutta sen toteutus esimerkiksi säätösalaojituksella ei aina onnistu (Bärlund et. al. 2005). Tälläisillä alueilla siirtyminen pienempää kuivatussyvyyttä vaativan kasvin viljelyyn voisi poistaa tämän ristiriidan. Bioenergiakasvina kasvatettava ruokohelpi voisi olla näille maille sopiva viljelykasvi. Ruokohelven korjuu tehdään kevättalvella maan ollessa roudassa, joten kuivatusta ei tarvita koneiden kantavuuden takia.

Tutkimuksen eräänä tavoitteena on selvittää kuivatussyvyyden vaikutus ruokohelven kasvuun ja tuottoon happamilla sulfaattimailla sekä erityisesti kuivatussyvyyden ja kasvin vaikutus valumaveden laatuun. Tutkimus koostuu laboratoriossa ja kasvihuoneessa toteutettavista kokeista sekä mittauksista koekentällä. Laboratoriossa tutkitaan maan fysikaalisten ominaisuuksien vaikutusta sulfaattimaiden hapettumiseen, hapettumisen nopeuteen sekä siinä syntyvien haitallisten aineiden määrään. Lisäksi selvitetään haitallisten aineiden liikkumista veden mukana ja maan rakenteen muuttumista hapettumisprosessien seurauksena. Suurten maanäytelieriöiden avulla selvitetään pohjaveden korkeuden vaikutusta maan pelkistymiseen ja hapettumiseen, sekä tämän vaikutusta happamien sulfaattimaiden soveltumiselle ruokohelven kasvualustaksi. Tutkimus on osa maatalousmetsätieteellisen tiedekunnan yhteistutkimushanketta "Peltobioenergiaketjut - raaka-aineen tuotanto ympäristöllisesti ja taloudellisesti kestävällä tavalla".

Tutkimus aloitettiin kesällä 2007 esikokeilla, joissa selvitettiin, voidaanko suuria maanäytelieriöitä käyttää pelto-olojen simulointiin. Maanäytelieriöiden etuna kenttäkokeisiin verrattuna on vedenkorkeuden muutosten kontrolloitu säätö, mittausten helpompi järjestäminen ja pienemmät perustamiskustannukset. Maanäytelieriöissä tapahtuvien muutosten vastaavuutta peltoolosuhteissa tapahtuviin muutoksiin selvitettiin vertaamalla lieriöistä saatuja tuloksia pellolta mitattuihin kasvukauden aikana tapahtuneisiin pohjaveden laadun muutoksiin.

Kenttämittaukset tehtiin samalla pellolla, jolta maanäytelieriöt oli otettu. Happamia sulfaattimaita esiintyy yleisesti Suomen rannikoilla muinaisen Litorina-meren rantaviivan alapuolisilla alueilla (Hartikainen 2001). Esimerkiksi osa Helsingin yliopiston Viikin koetilan pelloista on happamia sulfaattimaita.

Esikokeen toisena tavoitteena oli selvittää tutkimuksen käytännön toteutuksen ongelmia ja luoda toimiva mittausjärjestelmä ennen laajemman useita suuria maanäytelieriöitä käsittävän kokeen aloittamista ja kasvullisten jäsenten mukaanottamista. Käytännön toteutukseen kehitettiin tekniikka häiriintymättömien suurten maapatsaiden ottamiseen, toimiva vedensäätöjärjestelmä ja jatkuvatoimisten mittausten instrumentointi kahden suuren maanäytelieriön avulla.

\section{Aineisto ja menetelmät}

Esikokeeseen maanäytelieriöt otettiin Viikin koetilan Patoniityn pellolta, jonne asennettiin pohjavesiputkia pohjaveden korkeuden ja laadun seuraamiseksi. Pelto on maalajiltaan liejusavea, jonka savespitoisuus kasvaa maaprofiilissa syvemmälle mentäessä (kuva 1). Patoniityn pellolla massiivinen pelkistynyt maakerros alkaa $128 \mathrm{~cm}$ syvyydestä. Maanäytelieriöt otettiin siten, että lieriön pohjalle saatiin $20 \mathrm{~cm}$ massiivista hapettumatonta maata ja sen yläpuolelle $60 \mathrm{~cm}$ rakenteellista osittain hapettunutta maata. 

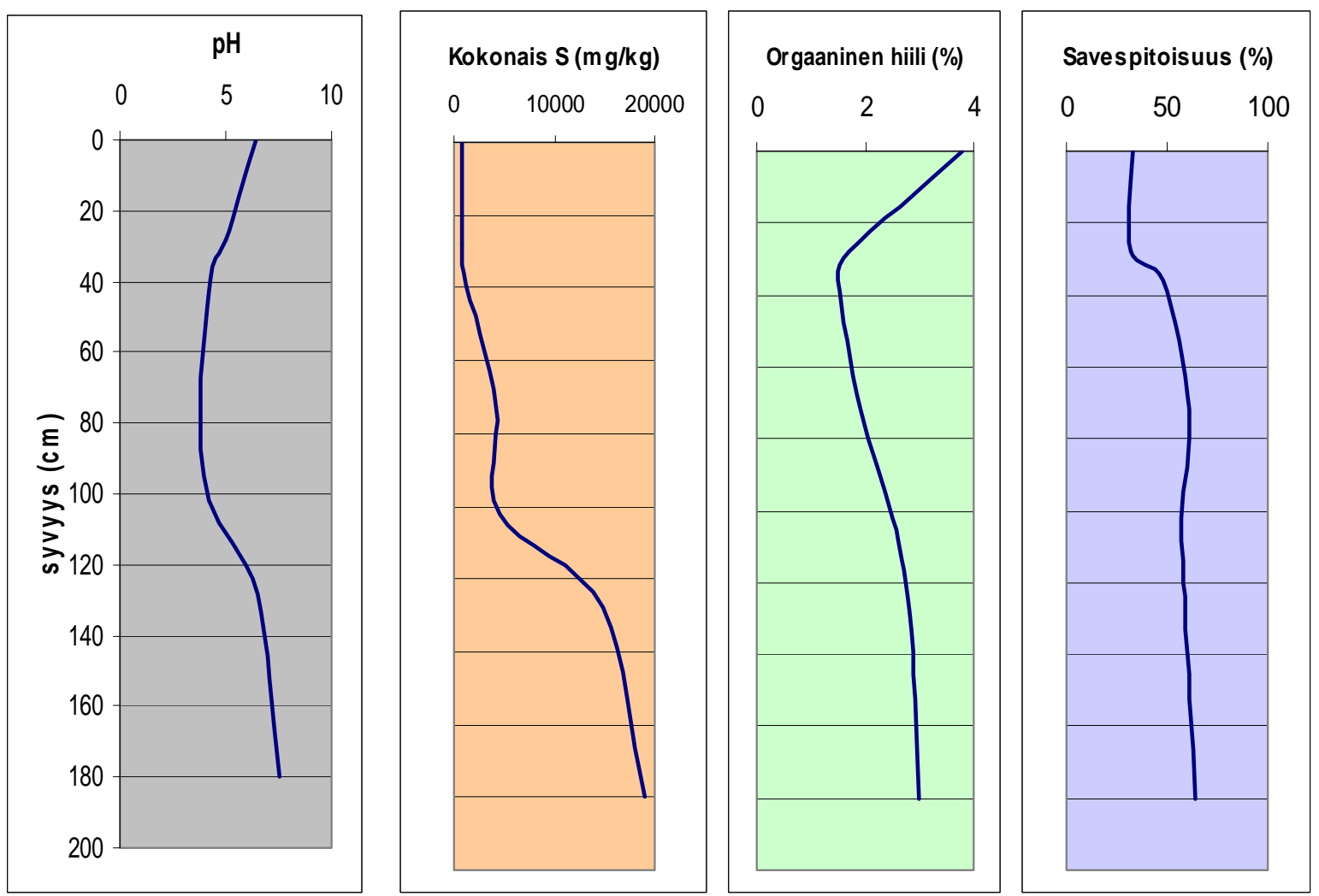

Kuva 1. Maan pH sekä kokonaisrikin, orgaanisen hiilen ja saveksen pitoisuus maaprofiilissa Viikin Patoniityllä.

\section{Maanäytelieriöiden ottaminen}

Maanäytelieriöt valmistettiin ulkohalkaisijaltaan $500 \mathrm{~mm}$ ja seinämän paksuudeltaan 14,6 mm PVC maaviemäriputkesta. Maaviemäriputki sahattiin $1000 \mathrm{~mm}$ mittaisiksi ja lieriön seinämiin reiät vedensyöttöjärjestelmää varten ja osa antureiden läpivienneistä (kuva 2).

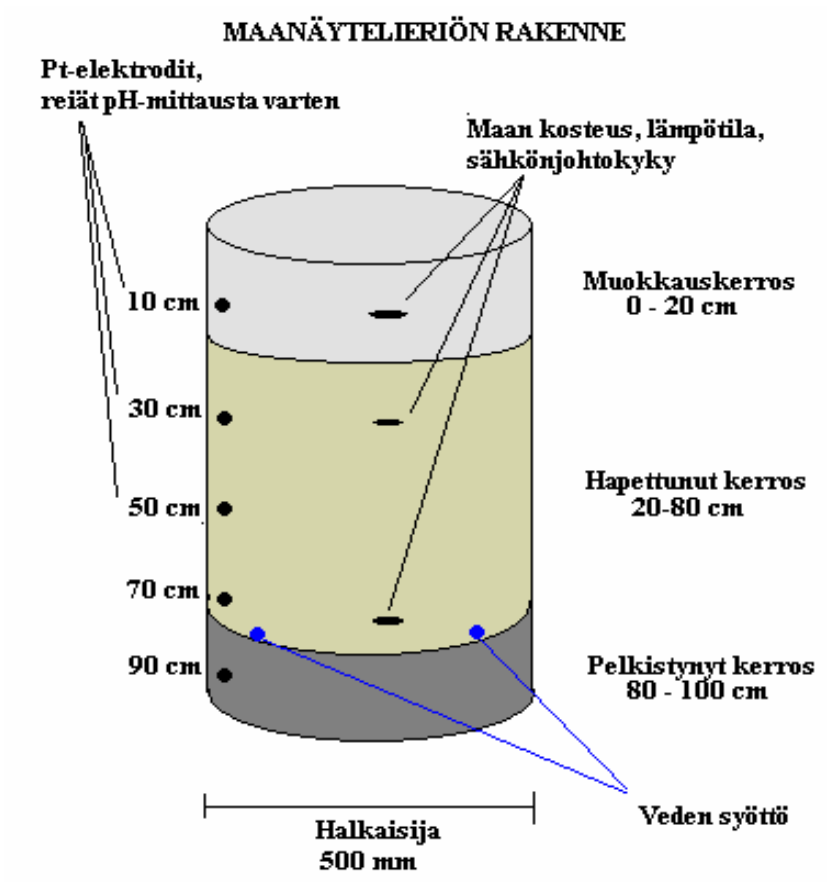

Kuva 2. Rakennekuva maanäytelieriöstä 
Matti Ylösmäki suunnitteli ja teki teräsputkesta leikkausterän, johon oli hitsattu harjaterästangot näytteen ylösvetämistä varten, sekä teräskannen, jolla kaivurin kauhan aiheuttama paine saatiin jakautumaan tasaisesti lieriön kehälle (kuva 3). Sen varmistamiseksi, että lieriöihin saatiin halutunlainen maanäyte, kaivettiin kaivinkoneella $70 \mathrm{~cm}: n$ kerros pintamaata pois. Näytteet otettiin siten, että leikkausterä asetettiin haluttuun syvyyteen kaivettun kaivannon pohjalle ja PCV:stä tehty maalieriö laskettiin leikkausterän päälle. Viimeiseksi lieriön päälle nostettiin teräskansi.

Maanäytelieriö päällä olevaa teräskantta kaivinkoneen kauhan kärjellä painaen lieriö upotettiin maahan lieriön ulkokehälle piirrettyyn merkkiin $(80 \mathrm{~cm})$ asti. Maanäyte irrotettiin maasta kaivamalla kaivurilla lieriön vierestä maa-aines pois ja kallistamalla lieriötä sivusuunnassa niin, että maapatsas leikkautui lieriön alareunasta. Lieriö vedettiin kuopan reunaa pitkin maanpinnalle kuormalavan päälle. Kuormalavalla leikkausterä ja teräskansi irrotettiin, ja lieriön alareuna puhdistettiin maa-aineksesta ja suljettiin maaviemäriputkea varten valmistetulla tulpalla. Lieriö nostettiin pystyyn kuormalavalle ja ylin $20 \mathrm{~cm}$ lieriöstä täytettiin muokkauskerroksen maalla. Toinen lieriö otettiin samalla tavoin ja molemmat kuljetettiin kuormalavalla verkkohalliin.

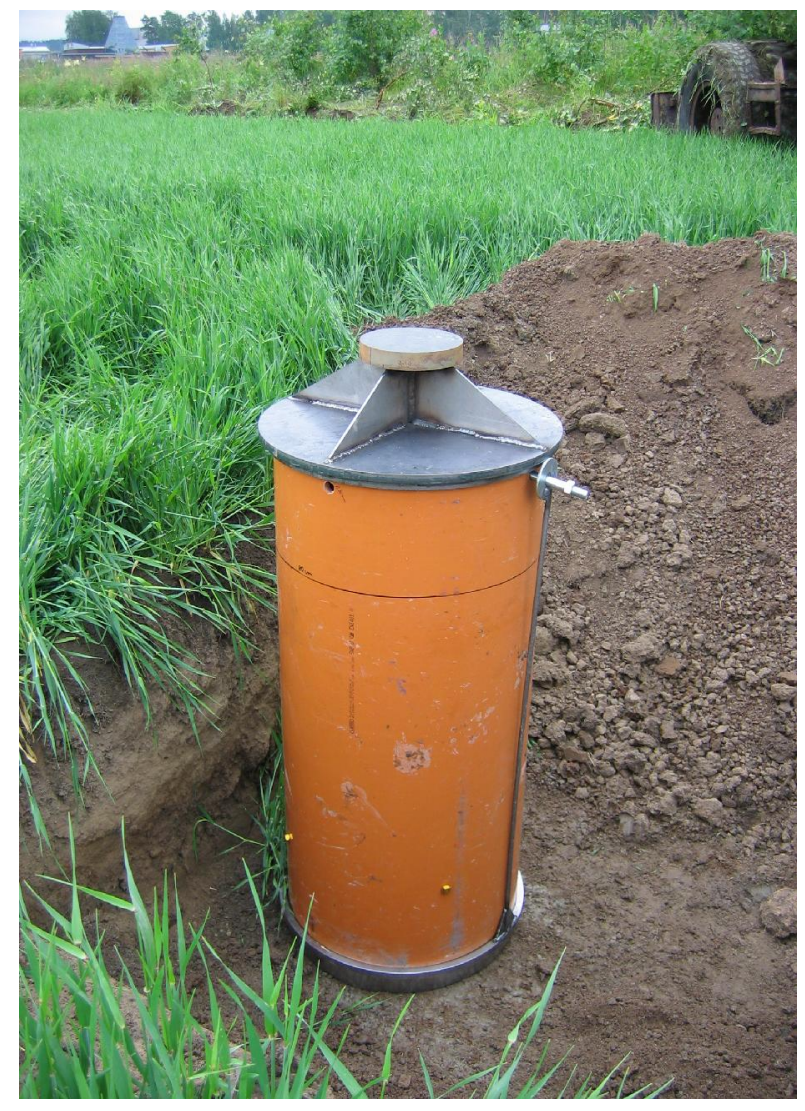

Kuva 3. Suuret maanäytelieriöt sahattiiin maaviemäriputkesta ja niiden maahan upottamista varten teetettiin teräksestä leikkausterä ja teräskansi alaspäin suuntautuvan paineen jakamiseksi lieriön reunoille (Kuva A.Simojoki 2007).

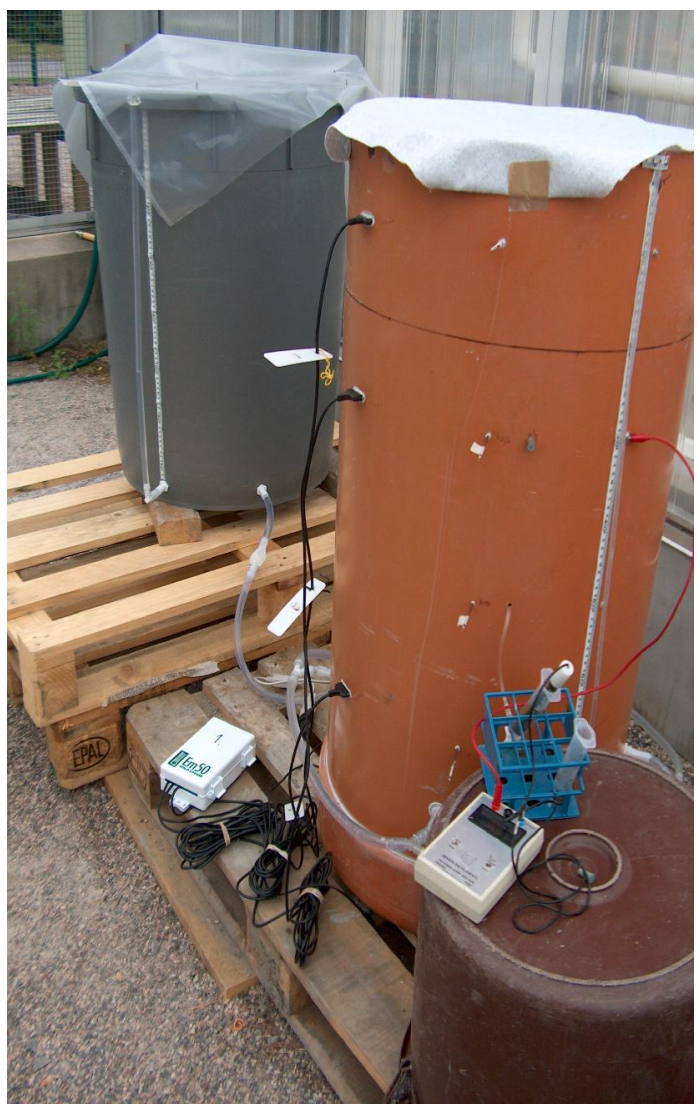

Kuva 4. Suuriin maanäytelieriöihin asennettiin vedensyöttöjärjestelmä massiivisen ja rakenteellisen maan rajapinnan yläpuolelle (kuva: S. Virtanen, 2007)

\section{Maanäytteiden vedensäätöjärjestelmä}

Verkkohallissa maanäytelieriöihin asennettiin veden säätöjärjestelmä (kuva 4). Vedensyöttöä varten lieriöihin oli porattu ennen näytteiden ottamista reiät $20 \mathrm{~cm}$ korkeudelle lieriön pohjasta. Tähän kohtaan maanäytettä otettaessa pyrittiin saamaan massiivisen ja rakenteellisen eli pelkistyneen ja hapettuneen maakerroksen rajapinta. Vedensyötön sijoitus valittiin maakerrosten rajapintaan, koska massiivisen pohjamaan vedenjohtokyky on lähes nolla ja rakenteellisen maan taas huomattavasti 
suurempi. Vesi syötetään lieröön neljästä tasavälein sen kehälle asennetusta liittimestä, joihin vesi ohjataan viereisestä vesisäiliöistä. Vedenpinnan korkeutta säiliöissä seurattiin säiliöiden seinämiin asennetun pohjavesiputken avulla.

\section{Mittausjärjestelmän instrumentointi}

Maassa tapahtuvia pohjaveden korkeuden vaihtelun aiheuttamia muutoksia seurattiin eri syvyyksille asennettujen mittausantureiden avulla. Antureilla mitattiin maan vesipitoisuutta, lämpötilaa, redoxpotentiaalia ja sähkönjohtavuutta jatkuvatoimisesti 10 minuutin välein muokkauskerroksesta, hapettuneesta kerroksesta ja pelkistyneestä kerroksesta. Maan vesipitoisuus, lämpötila ja sähkönjohtavuus mitattiin 50 mm pituisilla ECH20-TE antureilla (Decagon Devices). Redoxpotentiaalia mitattiin platinaelektrodeilla yhteisen referenssielektrodin $(\mathrm{Ag} / \mathrm{AgCl})$ ja suolasillan (kylläinen $\mathrm{KCl}$ ) avulla viidestä eri mittaussyvyydestä. Maan $\mathrm{pH}$-arvon muuttumista ja huokosveden koostumusta (Eijkelkamp Rhizon MOM $10 \mathrm{~cm}$ ) seurattiin samoista syvyyksistä kuin redoxpotentiaalia määräajoin tehtävin mittauksin. Jatkuvatoimisissa mittauksissa aineiston keräämiseen käytettiin dataloggereita (Agilent 34980A, Degacon Em50), joista tulokset siirrettiin tietokoneelle (kuva 5).

\section{JATKUVATOIMINEN MITTAUS}

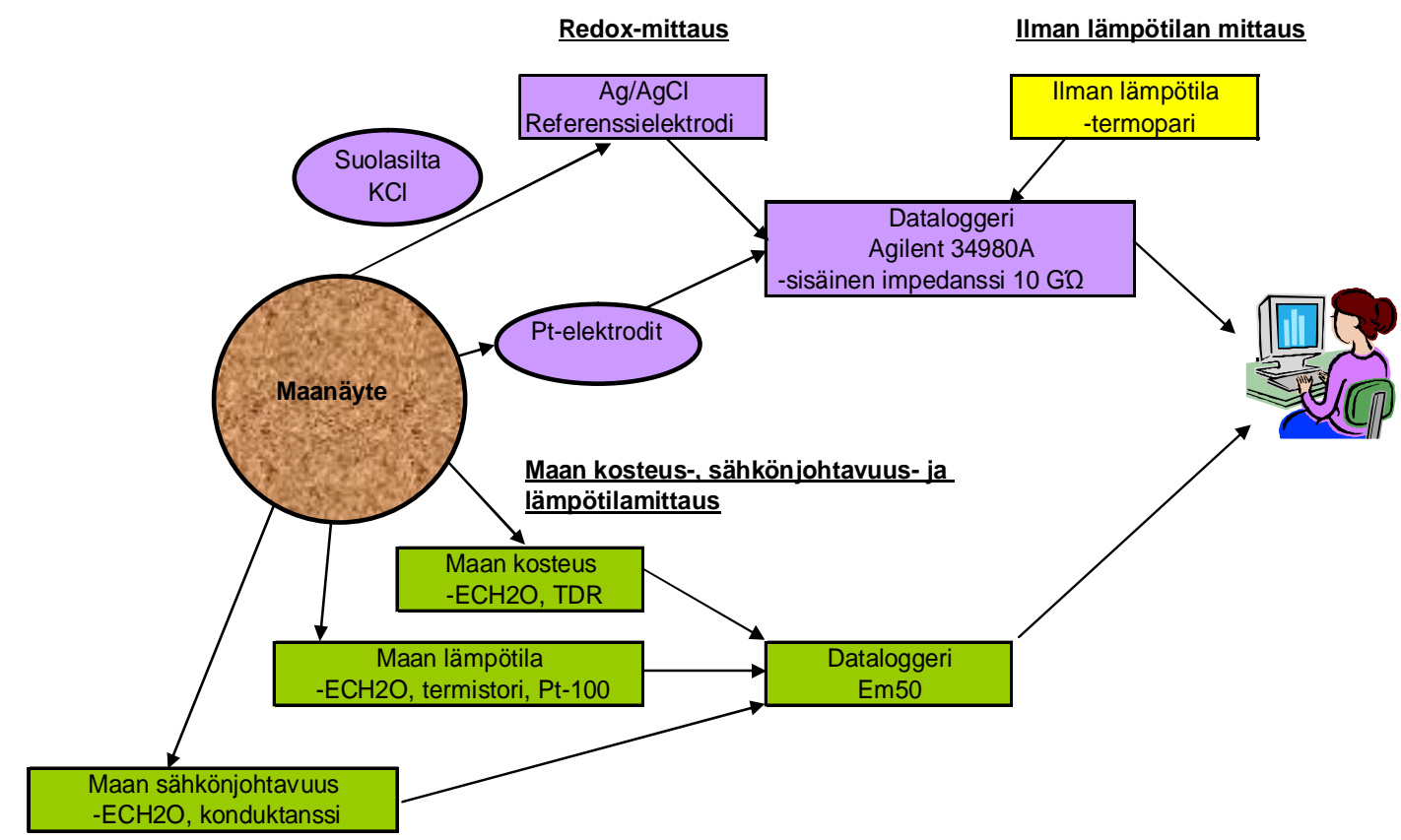

Kuva 5. Kaaviokuva maanäytelieriöiden jatkuvatoimisesta mittauksesta.

\section{Tulokset}

\section{Kokemuksia näytteiden otosta ja järjestelmän teknisestä toteutuksesta}

Esitutkimuksessa todettiin leikkaavan terän ja painetta tasapainottavan teräskannen tarpeellisuus, sillä lieriöiden maahan painaminen tasaisesti vaati koneen käyttäjältä ammattitaitoa. Teräskannen sileään pintaan sorvattu ura helpottaisi kaivinkoneen kauhan kärjen paikallaan pysymistä ja lieriön tasaista maahan painamista. Vedensyöttöjärjestelmän suunniteltu sijoitus maakerrosten rajapintaan oli ehdoton edellytys vedenkorkeuden säätelyn onnistumiselle. Toinen lieriö oli painunut muutaman sentin liian syvään, minkä vuoksi vedensäätöjärjestelmä jouduttiin myöhemmin siirtämään ylemmäs, jotta säätely saatiin toteutetuksi. Mittausantureiden läpivientien huolellinen tiivistäminen ja kierrelukitteen käyttö kierteissä estivät vuodot. Kumitulppa osoittautui kaikissa läpivienneissä tiiviiksi, mutta silikonimassa 
ei pysynyt tiiviinä jäätymisen jälkeen. Suolasiltoihin kerääntyvät ilmakuplat aiheuttivat ajoittain jatkuvatoimisen mittauksen keskeytymisen.

\section{Mittausjärjestelmän toimivuus}

Redox-potentiaalin mittauksissa käytettiin yhteistä referenssielektrodia, mikä edellytti suolasillan käyttöä (Linebarger 1975). Ennen suolasillan rakentamista selvitettiin referenssielektrodin ja platinaelektrodin etäisyyden vaikutusta mitattuun redox-potentiaaliin arvoon. Suolasillan ja platinaelektrodien välinen etäisyys on lieriöissä suurimmillaan $70 \mathrm{~cm}$. Maanäytelieriöissä referenssielektrodin etäisyydestä aiheutuva vaihtelu $(3 \mathrm{mV})$ oli pienempi kuin rinnakkaisten mittausten välinen vaihtelu $(6 \mathrm{mV})$. Jatkuvatoimisessa mittauksessa Pt-elektrodin ja referenssielektrodin välinen jännite-ero mitattiin sisätiloihin sijoitetulla Agilentin 34980A dataloggerilla. Jännite-ero välitettiin mittausyksikköön Pt-elektrodeista lattakaapelin ja referenssielektrodista koaksiaalikaapelin avulla, siirtoetäisyys oli keskimäärin $6 \mathrm{~m}$. Siirrossa tulokseen aiheutuvan kohinan suuruuden määrittämiseksi mitattiin redox-potentiaali manuaalisesti suoraan Pt- ja referenssielektrodista ja verrattiin vastaavana ajankohtana mittausyksikön antamia tuloksia. Pelkistyneessä kerroksessa keskimääräinen ero mittausten välillä oli pienin $38 \mathrm{mV}$ (kuva 6). Muissa kerroksissa keskimääräinen ero oli noin $100 \mathrm{mV}$, joka on suuruusluokaltaan sama kuin van Bochoven tutkimuksissa (van Bochove et al. 2002) .

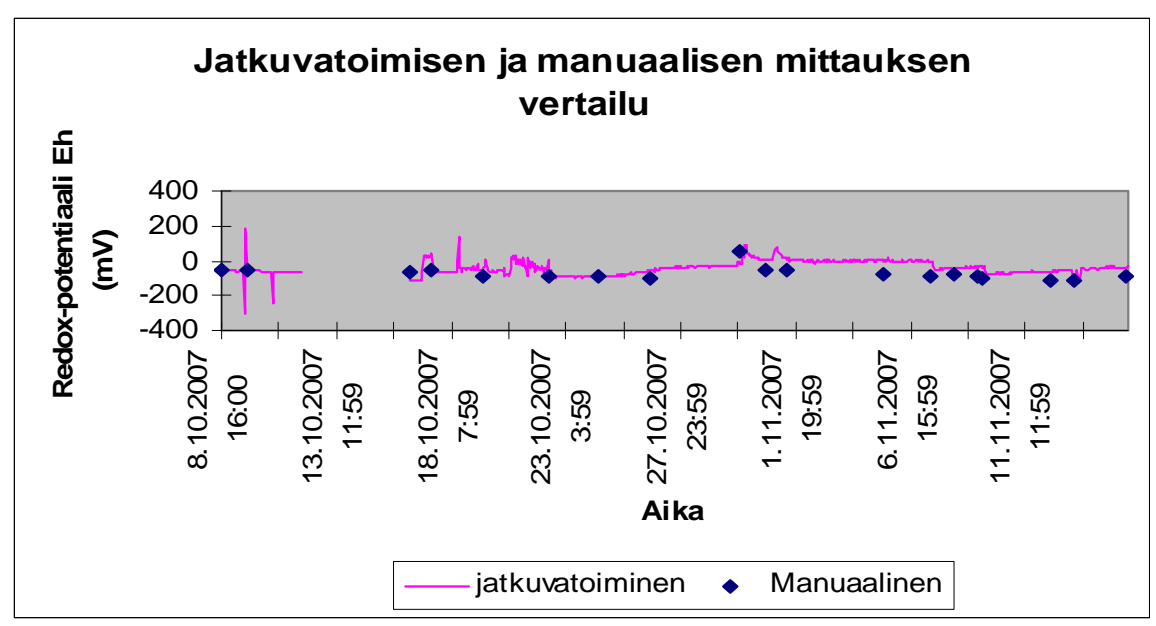

Kuva 6. Maanäytelieriössä 1 redox-potentiaali mitattuna Agilentin 34980A dataloggerilla ja manuaalisesti 90 cm:n syvyydessä.

\section{Maanäytelieriöiden ja kenttämittausten vertailu}

Koepellolla pohjaveden korkeuden vaihteluväli oli mittausjaksolla keskimäärin $45 \mathrm{~cm}$. Vain Patoniityn alavimmilla osilla pohjaveden pinta nousi maanpinnan tasolle muutamaksi päiväksi kesän ja syksyn rankkasateiden seurauksena. Alavimmalla osalla pohjavesi oli korkeimmillaan $6 \mathrm{~cm}$ maanpinnan alapuolella ja korkeammalla sijaitsevalla alueella $30 \mathrm{~cm}$ maan pinnan alapuolella. Maanäytelieriöissä pohjavesi säädettiin aluksi etäisyydelle $50 \mathrm{~cm}$ lieriön yläreunasta. Vedenpintaa nostettiin kolmesti, siten että se oli korkeimmillaan noin $6 \mathrm{~cm}: n$ etäisyydellä lieriön yläreunasta. Pohjaveden pH:n, sähkönjohtavuuden ja redox-potentiaalin muutokset pohjaveden korkeuden funktiona pellolla ja maanäytelieriöissä olivat samansuuntaisia. Kummassakin tapauksessa korkea pohjavedenpinta laski redoxpotentiaalia ja sähkönjohtavuutta ja nosti veden/maan $\mathrm{pH}$-arvoa. Maanäytelieriössä 1 , jossa $70 \mathrm{~cm}$ syvyydessä oleva maa-aines jäi pohjaveden pinnan alle heti kokeen alussa, redoxpotentiaali laski $150 \mathrm{mV}$ ja pH nousi arvosta 0,5 yksikköä. Tästä kerroksesta otetun huokosveden sähkönjohtavuus oli alussa $1300 \mu \mathrm{S} / \mathrm{cm}$ ja pohjaveden ollessa korkeimmillaan 900 $\mu \mathrm{S} / \mathrm{cm}$. Patoniityn alavimmalla osalla pohjaveden nousu maan pintaan nosti pohjaveden $\mathrm{pH}$-arvon lähelle neutraalia arvosta 4,5 ja sähkönjohtavuus laski $500 \mu \mathrm{S} / \mathrm{cm}$ keskikesällä mitatusta $1000 \mu \mathrm{S} / \mathrm{cm}$ arvosta. Redox-potentiaalin ja pohjaveden korkeuden muutoksen välinen yhteys maanäytelieriössä 1 ja Patoniityn peltolohkon alavimmalla osalla on esitetty kuvissa 7 ja 8. 


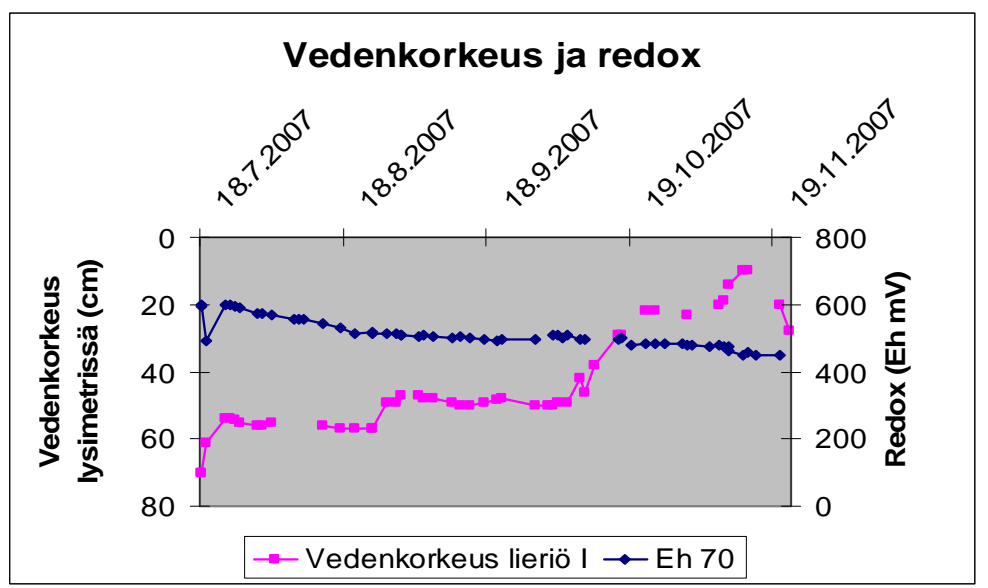

Kuva 7. Pohjaveden korkeuden vaikutus maan redoxpotentiaaliin $70 \mathrm{~cm}$ : n syvyydessä maanäytelieriössä 1.

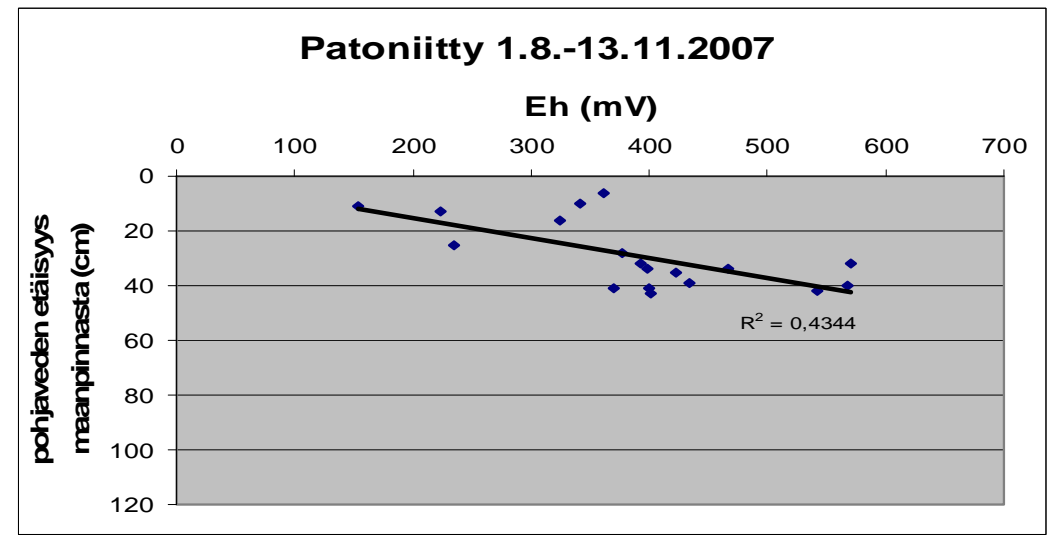

Kuva 8. Pohjaveden korkeuden ja redoxpotentiaalin välinen yhteys Patoniityn alavimmalla osalla tehtyjen mittausten perusteella.

\section{Johtopäätökset}

Esikokeesta saadut alustavat tulokset viittaavat siihen, että maanäytelieriöllä voidaan simuloida pellolla tapahtuvia pohjaveden muuutoksia ja seurata pohjaveden korkeuden vaikutusta maan ominaisuuksiin. Pohjaveden nostolla oli esitutkimuksessa $\mathrm{pH}$-arvoa nostava vaikutus kuten aiemmissa happamista sulfaattimaista tehdyissä tutkimuksissa on havaittu. Ruokohelven kasvukyky pohjaveden pinnan ollessa korkealla ja kasvin vaikutus maan ominaisuuksiin ja valumaveden laatuun on tutkimuksen seuraava vaihe.

\section{Kirjallisuus}

Bärlund, I., Tattari, S., Yli-Halla, M. \& Åström, M. 2005. Measured and simulated effects of sophisticated drainage techniques on groundwater level and runoff hydrochemistry in areas of boreal acid sulphate soils. Agricultural and Food Science 14(1): 98-111.

Hartikainen, H. 2001. Maaperä. Julkaisussa: Heinonen, R. (toim.). Maa, viljely ja ympäristö. 3. painos. WSOY, Porvoo. s. 9-89.

Linebarger, R. S., Whisler, F. D., Lance, J.C. 1975. A new technique for rapid and continuous measurement of redox potentials. Soil Sci. Soc.Amer. Proc. 39:375-377.

Roos, M. \& Åström, M. 2005. Hydrochemistry of rivers an acid sulphate soil hotspot area in western Finland. Agricultural and Food Science 14 (1): 24-33.

van Bochove, E., Beaushemin, S. \& Theriault, G. 2002. Continious Multiple Measurement of Soil Redox Potential Using Platinum Microelectrodes Soil Sci. Soc.Amer. Proc. 66:1813-1820.

Åström, M. \& Björklund, A. 1995. Impact of acid sulfate soils on stream water geochemistry in western Finland. Journal of Geochemical Exploration 55: 163-170. 